\title{
UTE' SIMAGERE (TENGKORAK BAGI ROH): HUBUNGAN MASYARAKAT DENGAN PRIMATA ENDEMIK DI MENTAWAI
}

\author{
Tresno $^{1}$
}

\begin{abstract}
Many think that the primate hunting is done by the Mentawai people caused the primate extinction in Mentawai whereas forest exploitation on Siberut Island has been going on for a long time like HPH, poaching, and development. Indeed, the Mentawai people have Arat Sabulungan guidance on their environment which not only regulate natural environment but the social and cultural environment. Based on the research of results found that the people of Buttui and Tepu' know their world is divided into two parts, namely purimanuaijat (porak, manua, baga, oinan and leleu); and sabulungan (Saikamanua, Si Bara Ka Baga, Saikoinan and Saikaleleu). The world purimanuaijat in fact both the living things and inanimate objects have a soul (simagere) and spirit (ketsat). So the Mentawai people should maintain the relationship. Because human life that always utilize nature, can trigger the relationship, so they do punen and puliaijat. Because the balance is not only about the world purimanuaijat, but also the world sabulungan. So the Mentawai people perform the hunting activity at the end of the ceremony, due to the hunt for a form of respect for the spirits of the ancestors, Saikaleleu and fellow creatures who are spirited and have spirits by making ute 'simagere. The ethno-ecological Mentawai people have a categorization of the environment that are uma, pumonean consisting of pumonean saina and also pumonean leleu or siburuk; and leleu. Leleu this is a place of hunting and place of life for 4 species of endemic primates in the Mentawai. One of them are bilou, joja, simakobu and also bokkoi. As for the pumonean saina and pumonean leleu, it is advantageous to these four primates at the time of food to the four species of primates will descend to the fruit field as well as the bokkoi who can go down to the ground to take surappik. Likewise some taboos that save some primates while for the ceremony is not always the ending ceremony of hunting, so the ceremony and hunting are the mechanism of the Mentawai people in balancing the natural, social and cultural environment with a balance for the Mentawai people about the relationship between the world of purimanuaijat and the world of sabulungan.
\end{abstract}

Keywords: Purimanuaijat World, Arat Sabulungan, Puliaijat, Hunting, Ethno-Ecology

Abstrak

Banyak yang mengira perburuan primata yang dilakukan masyarakat Mentawai menyebabkan kepunahan primata di Mentawai, padahal eksploitasi hutan di Pulau Siberut sudah terjadi sejak lama seperti HPH, perburuan liar, dan berbagai pembangunan. Sejatinya masyarakat Mentawai memiliki pedoman Arat Sabulungan mengenai lingkungannya, yang tidak hanya mengatur lingkungan alam saja tetapi juga lingkungan sosial dan budaya. Penelitian ini menggunakan pendekatan etnoscience dengan pemilihan informan secara purposive sampling. Peneliti menggunakan analisis Rappaport dan Etno-ekologi untuk melihat fenomena apa, bagaimana dan kenapa berburu dilakukan. Berdasarkan hasil penelitian masyarakat Buttui dan Tepu' mengenal dunia mereka terbagi menjadi dua yaitu purimanuaijat (porak, manua, baga, oinan dan leleu; dan sabulungan (Saikamanua, Si Bara Ka Baga, Saikoinan dan Saikaleleu). Adapun dunia purimanuaijat nyatanya baik itu benda hidup dan benda mati memiliki jiwa (simagere) dan roh (ketsat). Dikarenakan keseimbangan 
tersebut tidak hanya menyangkut dunia purimanuaijat, tetapi dunia sabulungan. Sehingga orang Mentawai melakukan upacara punen dan puliaijat dengan diakhiri berburu, dikarenakan berburu merupakan wujud dari menghormati roh-roh nenek moyang, Saikaleleu dan sesama makhluk yang berjiwa dan memiliki roh, dengan membuat ute' simagere. Setidaknya terdapat kategorisasi tentang lingkungan pada masyarakat Mentawia yaitu uma dengan pangurep iba, pumonean yang terdiri dari pumonean saina dan pumonean leleu/siburuk, dan leleu. Leleu ini lah menjadi tempat perburuan dan tempat kehidupan bagi 4 jenis primata endemik di Mentawai yaitu bilou, joja, simakobu dan bokkoi. Adapun dengan adanya pumonean saina dan pumonean leleu, menjadi keuntungan bagi ke empat primata ini pada waktu musim iba ke empat jenis primata ini akan turun ke ladang buah-buahan, begitu juga dengan bokkoi yang dapat turun ke tanah untuk mengambil surappik. Begitupun beberapa pantangan yang menyelamatkan beberapa primata, sedangkan untuk upacara tidak selalu upacara diakhiri dengan berburu. Sehingga upacara dan berburu merupakan mekanisme orang Mentawai dalam menyeimbangkan lingkungan alam, sosial dan budaya dengan keseimbangan bagi orang Mentawai mengenai hubungan antara dunia purimanuaijat dan dunia sabulungan.

Kata kunci: Dunia Purimanuaijat, Dunia Sabulungan, Puliaijat, B erburu, Etno-ekologi

\section{A. PENDAHULUAN}

$\mathrm{K}$ epulauan Mentawai terletak 85-135 $\mathrm{km}$ di lepas pantai barat Sumatera yang terpisah dari pulau utama Sumatera sejak 500 ribuan tahun yang lalu (Batchelor, 1979). Akibat terisolasi sekian lama, proses evolusi ekosistem di Kepulauan Mentawai hanya sedikit terpengaruh dengan pulau utama Sumatera. Spesies di Pulau Siberut mempunyai karakter yang lebih primitif dibandingkan dengan spesies yang ada di Sumatera. Oleh karena itu, Kepulauan Mentawai memiliki kekayaan spesies flora maupun fauna endemik yang tinggi. Telah tercatat lebih dari $65 \%$ dari mamalia dan $15 \%$ spesies fauna di Pulau Siberut adalah endemik atau tidak dapat ditemukan di tempat lain di dunia (CIl, 2002; Wilting dkk, 2012; Sargis dkk, 2014).

Keanekaragaman dan keendemikan flora dan fauna di Kepulauan Mentawai, menyebabkan Kepulauan tersebut tepatnya di Pulau Siberut dijadikan sebagai cagar biosfer oleh UNESCO. Kemudian, pada tahun 1993 berdasarkan Keputusan Menteri Kehutanan Nomor 407/Kpts-II/1993 didirikanlah Taman Nasional Siberut yang tujuanya untuk melindungi hutan di Mentawai terkhususnya satwa endemik yang mulai langka di Mentawai termasuk primata endemik di dalamnya. Setidaknya ada empat primata endemik di Mentawai yang dilindungi antara lain: (1) primata berhidung pesek atau simakobu (Simias concolor) dengan dua jenis subspesies S. $C$. concolor dan S. c. siberu (Chasen dan Kloss, 1927); (2) lutung atau joja (Presbytis potenziani) dengan dua subspesies $P$. $p$. potenziani dan P. p. siberu (Bonaparte, 1856); (3) beruk mentawai atau bokkoi (Macaca pagensis) dengan dua subspesies M. p. pagensis dan M. p. siberu (Fuentes dan Olson, 1995); dan (4) siamang kerdil atau bilou (Hylobates klossii) (Miller, 1903). Berdasarkan penelitian Whitaker (2006); Waltert dkk, (2008); dan IUCN/SSC Primate Specialist Group's Action Plan for Asian Primate Conservation, keempat primata di Mentawai ini mengalami penurunan jumlah populasi setiap tahunnya hingga terancam punah (critically endangered).

Aktivitas manusia yang berlebihan seperti deforestasi hutan, perburuan liar, eksploitasi sumber daya hutan dan hayati, dan lain-lain. Mengakibatkan keseimbangan ekosistem lingkungan alam di Mentawai menjadi terganggu dan berujung pada perubahan berbagai aspek lingkungan baik itu alam, sosial, dan budaya. Salah satu bukti nyata perubahan tersebut adalah pengurangan populasi keempat jenis primata endemik. Berdasarkan data red list IUCN keempat primata ini mengalami perubahan tiap tahunnya. Pada awalnya keempat primata ini berstatus endengered, kemudian pada tahun 2007 mengalami perubahan status antaranya bilou dan joja menjadi vulnarable. Sedangkan untuk simakobu menjadi endengered (terancam 
punah), dan bokkoi tetap dalam status critically endangered. Banyak hal yang menyebabkan kepunahan keempat primata ini diantaranya sudah sejak lama Pulau Mentawai menjadi incaran para HPH, sejak tahun 1972 antaranya PT CPSS, PT JSI, PT Kayu Siberut, PT Cirebon Agung bahkan saat ini kedua HPH di Pulau Siberut masih dalam kondisi beroperasi seperti Koperasi Andalas Madani yang diberikan konsensi pada tahun 2001, kemudian disusul dengan PT SSS yang diberikan konsensi pada tahun 2003 dan berbagai pembangunan di Pulau Siberut. Namun nyatanya beberapa stake holders baik LSM, pemerintah dan peneliti mengatakan bahwa kepunahan primata tersebut salah satu penyumbang terbesar akibat perburuan yang dilakukan etnis Mentawai seperti Teneza (1974) dan Tilson (1977) mengatakan dari perhitungan beberapa jumlah tengkorak primata di pulau Mentawai diperkirakan $77 \%$ diburu. Kesemua 4 primata yang berada di Pulau Siberut diburu untuk dimakan (Teneza dan Tilson, 1985:300). Dalam penelitian lainnya yaitu Quinten dkk (2014), yang memperkirakan primata endemik ini akan mengalami pengurangan populasi sebanyak 4.860-9.720 setiap tahun akibat diburu dan dikonsumsi oleh orang Mentawai. Bahkan setelah adanya perlindungan Pulau Siberut, pihak TNS yang awalnya bertujuan akan melindungi hutan di Pulau Siberut dari HPH dan meguatkan wacana masyarakat sebagai pemilik tanah adat, yang nyatanya penunjukan TNS membatasi wilayah masyarakat dan melarang perburuan primata di kawasan TNS. Polisi hutan bengasur-angsur ditambah dan patroli keamaan diintensifkan bahkan apabila masyarakat melanggar akan berakibat hukuman penjara (Darmanto dan Setyowati, 2012:210-211). Nyatanya penunjukan Pulau Siberut sebagai cagar biosfer dan pemberian batas-batas yang bertujuan akan melindungi hutan di Siberut, dan seakanakan kerusakan hutan dan kepunahan primata endemik merupakan perbuatan cara tradisional orang Mentawai. Namun nyatanya di balik hal tersebut beberapa pihak mengambil keuntungan akan hal itu

Menanggapi persoalan tersebut, etnis Mentawai mempunyai pedoman dalam menghadapi perubahan lingkungan yang terjadi di Mentawai. Maka dari itu kebudayaan dijadikan pedoman etnis
Mentawai dalam menghadapi segala perubahan yang terjadi di Mentawai. Di dalam kebudayaan Mentawai tidak hanya mengatur atau tidak hanya dijadikan pedoman dalam menanggapi perubahan lingkungan alam saja, tetapi juga pada lingkungan sosial dan budaya. Hal tersebut telah diatur dalam kepercayaan tradisional etnis Mentawai yaitu Arat Sabulungan ${ }^{1}$. Etnis Mentawai menganggap agar kehidupan sosial dan budaya mereka tetap belangsung, mereka juga harus menjaga lingkungan alam ${ }^{2}$. Dengan hal itu menuntut etnis Mentawai melakukan berbagai tindakan untuk mengembalikan perubahan lingkungan yang terjadi di Mentawai seperti semula, sesuai dengan ajaran nenek moyang mereka. Salah satu bentuk tindakan nyata mereka adalah dengan melakukan berbagai upacara ritual. Upacara inilah yang dijadikan sebagai proses penyeimbang lingkungan alam, sosial dan budaya masyarakat Mentawai, agar hubungan antara dunia nyata dan dunia supranatural dapat saling berhubungan. Hubungan tersebut saling memberi dan menerima fungsinya masing-masing, agar kedua alam tersebut tetap dalam keadaan seimbang ${ }^{3}$. Untuk menjaga prinsip keseimbangan tersebut, segala sesuatu yang dilakukan etnis Mentawai harus meminta izin terlebih dahulu dengan dunia supranatural. Maka dari itu, upacara merupakan keharusan bagi etnis Mentawai dalam mengatur segala aktifitas mereka yang mana dapat mengancam kerusakan alam nyata, termasuk aktifitas berburu di dalamnya.

Berkaitan dengan aktifitas perburuan yang mana menyebabkan pengurangan jumlah populasi primata endemik di Mentawai. Dikarenakan di satu sisi upacara merupakan sebuah mekanisme yang dilakukan etnis Mentawai dalam menyeimbangkan kembali lingkungan. Di

\footnotetext{
${ }^{1}$ Kepercayaan Arat Sabulungan yang dijadikan masyarakat Mentawai sebagai aturan dalam menginterpretasi lingkungan mereka. Arat Sabulungan ini menganggap bahwa dunia yang ditinggali masyarakat Mentawai terbagi menjadi dua yaitu dunia nyata dan dunia supranatural. Kedua dunia ini harus berjalan selaras.

${ }^{2}$ Sesuai dengan ide bahwa budaya itu lebih konservatif

${ }^{3}$ Sesuai dengan prinsip ekosistem atau prinsip reciprocity
} 
sisi lain upacara akan diakhiri dengan berburu, karena berburu merupakan penutup dalam setiap upacara yang dilangsungkan (Rudito, 2013). Namun berburu tetap saja dilakukan di Mentawai, karena itu sudah menjadi bagian dari sistem kepercayaan dan sistem mata pencaharian. Sudah sejak lama etnis Mentawai berburu khususnya berburu primata, karena primata merupakan hewan yang sakral dalam kebudayaan etnis Mentawai. Dikarenakan primata merupakan media prantara yang digunakan dalam keberlangsungan upacara serperti tengkorak primata. Tengkorak primata dijadikan sebagai penghubung atau media keberlangsungan upacara. Pemanfaatan tengkorak primata ini antara lain dijadikan; ute' simagere ${ }^{4}$ dan syarat ritual eneget ${ }^{5}$. Dari penjelasan di atas menunjukan bahwa etnis Mentawai melakukan upacara untuk menselaraskan kembali sesuatu yang telah dirusak termasuk penurunan jumlah primata itu sendiri. Jika tujuan etnis Mentawai melakukan upacara untuk penyelarasan

\footnotetext{
${ }^{4}$ Ute' simagere merupakan tengkorak primata yang digantung dan disusun di ruang tengah uma bersama tengkorak buruan lainnya. Ute' simagere inilah yang digunakan untuk menghubungkan roh-roh di hutan dengan roh-roh di uma melalaui prantara Sikerei ${ }^{4}$, sehingga pada saat berburu hewan yang akan diburu menjadi dekat kepada si pemburu. Hal ini akan mempermudah pemburu untuk menangkap hewan yang diburunya termasuk primata. Selain tengkorak primata dibuat menjadi ute' simagere, tengkorak primata juga dijadikan sebagai jaraik. Jaraik ini juga digunakan sebagai penghubung antara dunia nyata dan dunia gaib untuk melindungi uma. Tidak hanya itu rumah yang memiliki banyak tengkorak memperlihatkan status sosial seseorang. Karena hasil tangkapan hewan yang banyak meningkatkan status sosial orang. Sehingga semakin banyak tangkapan dan tengkorak yang disusun rapi di uma, semakin memperlihatkan status sosial yang tinggi di Mentawai dan semakin memperlihatkan seringnya keluarga tersebut melakuan aktifitas berburu. Dengan demikian berburu primata merupakan bagian penting dalam kehidupan sosial dan budaya masyarakat Mentawai.

${ }^{5}$ Ritual eneget adalah salah satu ritual untuk mempersembahkan primata kepada roh-roh agar anak laki-laki yang baru lahir dapat pintar berburu.
}

kembali antara dunia nyata dengan dunia supranatual, namun mengapa berburu primata yang dimanfaatkan sebagai media prantara dalam upacara seperti ute' simagere dan ritual eneget masih dilakukan? Apakah dengan melakukan pengurangan populasi primata akan menyebabkan alam menjadi seimbang atau apakah etnis Mentawai memiliki cara agar menyeimbangkan kembali populasi primata tersebut?

Jika mengikuti aturan adat yang diwariskan oleh nenek moyang etnis Mentawai yang berpedoman dengan nilainilai kepercayaan Arat Sabulungan, maka etnis Mentawai tidak hanya menyelaraskan lingkungan sosial dan budaya saja, tetapi lingkungan alam juga akan diselaraskan. Dengan demikian menjadikan masyarakat lebih konservatif dalam menjaga lingkungannya, karena Arat Sabulungan mengatur hubungan masyarakat dengan lingkungan secara keseluruhan, tidak hanya lingkungan dunia nyata tetapi juga lingkungan dunia supranatural. Akibat dari perburuan, ekosistem menjadi terganggu maka dari itu perlunya mengembalikan ekosistem seperti semula dengan cara melakukan upacara. Namun di balik upacara dan aktifitas berburu peneliti tidak melihat lingkungan alam mengalami keseimbangan, padahal dalam Arat Sabulungan terdapat nilai-nilai yang mengatur kesejahteraan hidup yang harus selaras dengan lingkungan alam, sosial dan budaya. Secara idealnya ketika etnis Mentawai melakukan kerusakan baik itu kerusakan dunia nyata maupun dunia supranatural, mereka memiliki cara dalam memperbaiki lingkungannya yang sudah diatur dalam kebudayaan etnis Mentawai yang bersumber dalam Arat Sabulungan. Dengan demikian etnis Mentawai menyadari akan tindakanya yang dapat merusak lingkungan alam. Namun mengapa masih tetap saja masyarakat melakukan tindakan perburuan primata yang nantinya digunakaan sebagai media prantara dalam upacara? Jika kita melihat upacara sebagai mekanisme penyeimbang lingkungan alam, sosial dan budaya. Lalu seyogyanya, keseimbangan yang bagaimanakah yang dimaksud dalam kebudayaan masyarakat Mentawai?

Adapun dalam artikel ini penulis membahas secara lebih mendalam tentang hubungan masyarakat Mentawai dengan 
lingkungan khususnya primata endemik di Mentawai dengan menganalisis pengetahuan masyarakat tentang aktifitas perburuan dan menganalisis mengenai hubungan primata dalam keseimbangan alam, sosial dan budaya di Mentawai yang mana dijadikan ute' simagere, sehingga menjadi penting bagi kebudayaan orang Mentawai.

\section{B. METODE}

$\mathrm{P}$ enelitian ini dilakukan di dua dusun yaitu di Desa Madobag, Pulaggajat (dusun) Buttui Kecamatan Siberut Selatan dan dilanjutkan di Desa Sagulubbeg, Pulaggajat Tepu', Kecamatan Siberut Barat Daya. Adapun penelitian ini menggunakan pendekatan etnoscience yang mana pendekatan ini memandang bahwa sistem pengetahuan adalah bagian penting dalam kehidupan manusia dan kelompoknya. Pendekatan ini berupaya menemukan makna dari suatu kebudayaan yang mana untuk memahami fenomena alam tersebut lebih didasarkan atas cara berpikir manusia (kognitif) yang dikajinya (Poerwanto, 2006:40). Menurut Hussel, fenomena adalah sesuatu yang sudah ada dalam persepsi dan kesadaran individu yang sadar tentang sesuatu hal (benda, situasi, dan lain-lain) (dalam Arifin dkk, 2005:58). Maka dari itu penelitian ini bersifat descriptif dan holistic dengan mendiskripsikan fenomena-fenomena yang nyata dalam masyarakat dan lingkungan, guna mendapatkan hubungan masyarakat dengan lingkungan dari sudut pandang masyarakat itu sendiri (natives point of view). Pendekatan etnoscience sejalan dengan pemikiran Goodenough yang mengatakan kebudayaan adalah suatu sistem kognitif yang terdiri dari pengetahuan, kepercayaan, dan nilai-nilai yang berada dalam pikiran anggota-anggota individual masyarakat (dalam Kalangie, 1994:1). Dari penjelasan tersebut, peneliti akan mencoba menganalisis fenomena prilaku dan material pada etnis Mentawai terhadap primata endemik di Mentawai. Dengan menggunakan teori-teori dan konsep-konsep Rappaport dan Etno-ekologi dalam menganalisis pengetahuan etnis Mentawai dalam memaknai fenomena prilaku dan material itu sendiri. Dengan melihat hubungan masyarakat dengan lingkungan alam khususnya primata edemik di Mentawai. Oleh karena itu untuk memahami berbagai prilaku seseorang peneliti harus memahami sistem berpikir mereka yang dipandang dari sudut pandang obyek yang diteliti maupun dari sudut pandang peneliti (Poerwanto, 2006:38). Di sini peneliti melakukan studi ke lapangan melihat fenomena masayarakat Mentawai dalam melakukan tindakan berburu primata yang mana nantinya digunakan sebagai media ute' simagere dan ritual eneget berdasarkan pandangan masyarakat itu sendiri (emik) yang kemudian akan dianalisis peneliti (etik) untuk menjelaskan dibalik fenomena tersebut. Untuk mendapatkan data tersebut, peneliti mempelajari bahasa Mentawai, melakukan observasi partisipasi dan wawancara secara mendalam serta melakukan pendokumentasian untuk mendukung data. Adapun dalam taksonomi dan klasifikasi itu terkandung pernyataan-pernyataan atau ideide masyarakat yang kita teliti mengenai lingkunganya. Taksonomi atau klasifikasi yang terungkap dalam berbagai istilah-istilah lokal itu biasanya berisi informasi mengenai lingkungan yang penting untuk mendapatkan etnoekologi dari masyarakat yang kita teliti. Taksonomi, klasifikasi dan makna-makna referensinya perlu dideskripsikan oleh peneliti. Akhirnya peneliti memformalisasikan aturan-aturan perilaku terhadap lingkungan yang dianggap tepat dari perspektif masyarakat (Ahimsa, 1997:54-55 dalam Lahajir, 2001:54). Dengan demikian penelitian ini tidak saja menjelaskan bagaimana fenomena itu terjadi, tetapi yang terpenting mememahami apa yang dibalik fenomena tersebut (Arifin dkk, 2005:62), dan mengapa fenomena tesebut masih saja dilakukan. Maka dari itu peneliti akan mengalasis penelitian ini dengan pendekatan Rappaport dan Etnoekologi. Adapun Informan dipilih dengan teknik purposive sampling yang mana sebanyak 6 suku di Pulaggajat Buttui dan 5 suku di Pulaggajat Tepu'.

\section{HASIL DAN PEMBAHASAN \\ ebudayaan menurut Suparlan
merupakan keseluruhan pengetahuan
yang dipunyai manusia sebagai} makhluk sosial. Isinya berupa perangkat model pengetahuan yang secara selektif dapat digunakan untuk memahami dan 
menginterpretasi lingkungan yang dihadapi, mendorong dan menciptakan tindakan yang diperlukan. Kebudayaan dipakai manusia untuk berdaptasi dan menghadapi lingkungan tertentu (alam, sosial dan budaya) agar manusia dapat melangsungkan hidupnya dan memenuhi kebutuhanya, serta hidup lebih baik (Suparlan, 2004:158). Maka dari itu dalam kebudayaan inilah yang berisikan pengetahuan, kepercayaan masyarakat Mentawai sebagai pedoman dalam menghadapi, memahami, memaknai dan menginterpretasi lingkungan alam, sosial dan budaya. Hal tersebut termaktub dalam sistem kepercayaan etnis Mentawai yaitu Arat Sabulungan. Arat Sabulungan inilah yang mencangkup seluruh pengetahuan, kepercayaan, adat istiadat masyarakat Mentawai mengenai lingkungan alam, sosial dan budaya mereka yang mana Arat Sabulungan merupakan adat, aturan, budaya orang Mentawai yang mengatur bagaimana menjadi orang Mentawai (simantawol) dan dalam Arat Sabulungan ini mereka mempercayai bahwa setiap makhluk hidup dan mati dalm wujud apapun memilki jiwa (simagere) dan roh (ketcat). Maka dari itu untuk menyeimbangkan jiwa dan roh tersebut orang Mentawai menggunakan daun-daunan (bulungan/buluat) yang diperantarai kerei melalui upacara untuk memanggil, melindungi, mengusir, membujuk, berdialog dan mendamaikan antara dunia nyata dan dunia supranatural (bandingkan Coronese, 1986; Mulhadi, 2008, dan Delfi, 2012). Dengan begitu Arat Sabulungan ini lah yang mengatur hubungan antara manusia dengan manusia, manusia dengan lingkunganya (biotik dan abiotik), dan manusia dengan dunia gaib terkhususnya dengan penguasa alam semesta/Tuhanya.

Setidaknya masyarakat Mentawai mengenal dua sisi kehidupan yang saling berdampingan, saling bertentangan dan saling membutuhkan keseimbangan. Dalam kehidupan ini menurut Aman Nama dan Aman Jaggau, semua isi alam diibaratkan seperti manusia yang dapat hidup/menghidupakan dan dapat mati/mematikan. Menurut mereka, seperti halnya sungai yang dapat memberi kehidupan, namun disisi lain dapat memberikan kematian bagi manusia. Dikarenakan dapat menimbulkan bahaya bagi manusia, begitu juga dengan hutan, leleu, dan lain-lain yang dapat mengancam kehidupan manusia (bandingkan Schefold, 1988). Adapun kehidupan tersebut yaitu kehidupan dunia nyata, kehidupan dunia nyata ini lebih dikenal dengan purimanuaijat, semua makhluk yang nampak secara empiris baik itu makhluk hidup maupun makhluk mati yang berada di bumi (porak/baga), langit (manua), hutan dengan segala isinya (se'se' dan pangureman), sungai (oinan) dan leleu (leleu). Hal itu juga diperkuat dengan asal mula kehidupan dengan mitologi orang Mentawai yang mereka sebut dengan pumumuan atau titibuat (sejarah), hampir semua mitologi yang diceritakan menjelaskan asal muasal dunia puimanuaijat untuk apa, siapa dan mengapa diciptakan seperti mitologi joja diceritakan Aman Ruamanai yang mana joja berasal dari manusia dan merupakan awal cerita dari berbagai jenis hewan buruan yang nantinya dimanfaatkan untuk beburu dalam upacara atau cerita yang diungkapkan Aman Tarit, asal muasal sagu, babi, ayam, simaligai dan sipageta sabbau yang awalnya mereka tidak kenal, dan akhirnya akibat simaligai dan sipageta sabbau mereka mengenal makanan untuk upacara, sikerei, uma dan berbagai cerita lainnya (lihat juga Spina, 1981; Tulius, 2012, dan Tresno, 2017).

Begitu juga dengan dunia yang tidak nyata (supranatural), merupkan dunia yang tidak terlihat secara kasat mata namun dapat dirasakan keberadaanya, diyakini, dan terkadang meperlihatkan diri dengan berbagai cara, dan kehidupan dunia supranatural ini juga dapat memberikan ancaman bagi kehidupan dunia nyata terkhususnya kehidupan manusia. Kehidupan inilah yang disebut orang Mentawai dengan sabulungan, setelah jiwajiwa mereka mati maka jiwa mereka akan kembali ke dunia sabulungan, dunianya para roh. Dalam wujud apapun dalam dunia supranatural terdapat berbagai macam roh, dan dalam setiap roh tersebut terdapat penguasa. Adapun masyarakat Mentawai membaginya sebagai berikut yaitu langit (manua) dengan penguasanya Saikamanua, tanah (baga) dengan penguasanya Si Bara Ka Baga/Si Bara Ka Porak, air (oinan) dengan penguasanya Saikaoinan dan leleu (leleu) dengan penguasanya Saikaleleu/Si Bara Ka Leleu. Sejatinya dalam kehidupan 
masyarakat Mentawai mereka meyakini baik makhluk hidup dan makhluk mati, semuanya memiliki jiwa (simagere) dan roh (ketsat) masing-masing. Maka dari itu tidak hanya penguasa saja yang tinggal dalam dunia sabulungan, namun makhluk hidup atau makhluk mati terdapat berbagai sebutan roh baik (mareu') ataupun roh jahat (simakataik) seperti saukkui, pitok, sanitu, bajou dan berbagai roh jahat yang berada di sungai seperti sikoinan dan di leleu seperti sabeu talinga, sikataik loinak dan silakikiow.

Adapun antara roh dan jiwa yang berada di dunia nyata dan dunia sabulungan, perlulah diseimbangkan berdasarkan keyakinan etnis Mentawai. Pada kenyataanya etnis Mentawai yang selalu memanfaatkan lingkungannya untuk memenuhi kebutuhan sehari-hari baik itu untuk memenuhi kebutuhan mereka, dari tempat tinggal atau mereka sebut uma, untuk kebutuhan konsumsi mereka seperti berladang dengan menanam sagu, keladi, pisang, kelapa, dan buah-buahan lainnya. Selain itu masyarakat Mentawai juga berternak babi dan ayam. Namun pada waktu tertentu mereka juga menangkap ikan, belut, dan kura-kura di sungai dan pada akhinya mereka juga melakukan perburuan di leleu untuk mengakhiri aktifitas mereka dalam upacara.

Sejalan dengan pemikiran

Rappaport mengenai hal ini dalam populasi ekosistem yang merupakan sekumpulan organisme yang memiliki karakteristik tertentu untuk saling menjaga sebuah hubungan material dengan komponen lain dari ekosistem (Rappaport, 1968:97). Sebagaimana yang sudah dijelaskan di atas, bahwa lingkungan alam mereka merupakan bagian dari lingkungan supranatural. Maka setiap elemen lingkungan purimanuaijat dan sabulungan harus saling menjaga dan saling memberi.
Adapun pemanfaatan lingkungan dunia nyata yang dapat menganggu lingkungan dunia supranatural. Maka dari itu hubungan tersebut perlulah dijaga, dengan cara kedua hubungan tersebut tetap saling berhubungan satu sama lain, maka dari itu masyarakat Mentawai melakukan upacara (punen dan puliaijat), agar antara dunia purimanuaijat dan dunia sabulungan tetap dalam keadaan seimbang. Namun tidak hanya sebatas upacara sebagai proses keseimbangan, keterkaitan akan setiap rohroh penguasa, ketakutan akan roh-roh penguasa baik roh hutan, roh sungai, roh leleu yang dapat membahayakan mereka ketika upacara sudah selesai, dan roh manusia itu sendiri maupun makhluk hidup lainnya. Jika hubungan manusia dengan penguasa langit dan roh-roh nenek moyang mereka sudah dilakukan melalui upacara. Sejatinya hubungan tersebut belumlah selesai, dikarenakan jika salah satu elemen terganggu maka elemen lainnya juga dapat terganggu, misalkan mereka telah melakuan upacara untuk membuat uma persembahan telah diberikan kepada roh penguasa langit dan nenek moyang mereka, namun ketika upacara tersebut telah selesai, dan mereka pergi kembali ke leleu, maka ketika mereka hendak pergi ke leleu dan hendak melewati sungai, elemen dari sungai dan leleu dapat mengancam jiwa mereka juga. Maka dari itu masyarakat Mentawai melakukan aktifitas berburu untuk menutup rangkaian upacara yang mereka lakukan dengan memberikan persembahan dan membuat ute' simagere. Maka dari itu proses berburu inilah untuk melihat upacara mereka telah berhasil dan roh-roh penguasa langit, bumi, sungai dan leleu telah mengizinkan mereka untuk kembali beraktifitas. Adapun ada beberapa upacara yang akan ditutup dengan berburu dapat dilihat pada tabel di bawah ini;

Tabel 1. Macam-Macam Upacara

\begin{tabular}{|c|c|c|c|c|}
\hline No & $\begin{array}{l}\text { Nama } \\
\text { Upacara }\end{array}$ & Jenis Upacara & Fungsi Upacara & $\begin{array}{l}\text { Macam-Macam } \\
\text { Upacara }\end{array}$ \\
\hline 1 & Punen & $\begin{array}{lr}\text { Upacara Lingkaran } \\
\text { Kehidupan } r \text { (Life } \\
\text { Cycle) juga dikenal } \\
\text { dengan upacara } \\
\text { perayaan, kata punen } \\
\text { juga merujuk dialek } \\
\text { selatan }\end{array}$ & $\begin{array}{l}\text { Tidak bertentangan dengan } \\
\text { bakkat katsaila atau suatu } \\
\text { kondisi yang tidak mengancam } \\
\text { roh-roh dan jiwa-jiwa pada } \\
\text { keluarga kami yang berguna } \\
\text { untuk membersihkan, } \\
\text { mengenalkan, dan menguatkan } \\
\text { jiwa makhluk hidup (tidak ada }\end{array}$ & $\begin{array}{l}\text { punen matutu, punen } \\
\text { lalai angalou, punen } \\
\text { pangambok, punen } \\
\text { abinen, punen } \\
\text { eneget, punen } \\
\text { sungunen/sogunei, } \\
\text { punen pashipiat shot, } \\
\text { punen matitik, punen }\end{array}$ \\
\hline
\end{tabular}




\begin{tabular}{|c|c|c|c|c|}
\hline & & & $\begin{array}{l}\text { berburu, hanya ada berburu } \\
\text { pada punen eneget) }\end{array}$ & $\begin{array}{l}\text { putalimoghat, punen } \\
\text { panasaik, punen } \\
\text { sururuk, punen eeruk, } \\
\text { punen labak, punen } \\
\text { simagere, dan punen } \\
\text { paabad }\end{array}$ \\
\hline 2 & Puliaijat & $\begin{array}{l}\text { Upacara } \\
\text { Keseimbangan } \\
\text { (Equlibrium Harmony) } \\
\text { juga dikenal dengan } \\
\text { upacara besar }\end{array}$ & $\begin{array}{l}\text { Betentangan dengan bakkat } \\
\text { katsaila atau mengancam jiwa- } \\
\text { jiwa yang berguna untuk } \\
\text { memintak izin dan mengusir roh } \\
\text { jahat pada jiwa makhluk hidup } \\
\text { (harus ada berburu) }\end{array}$ & $\begin{array}{l}\text { puliaijat uma, puliaijat } \\
\text { abag, puliaijat } \\
\text { tinunglu/pumonean, } \\
\text { puliaijat } \\
\text { pabetei/mabesik, dan } \\
\text { puliaijat pasimatei } \\
\text { (saukkui sabulungan) }\end{array}$ \\
\hline 3 & Lia & Upacara Kecil & $\begin{array}{l}\text { Pesta kecil tidak perlu berburu, } \\
\text { tidak ada tarian (muturuk } \\
\text { laggai), hanya ada ayam }\end{array}$ & $\begin{array}{l}\text { Lia sagu, dan lia } \\
\text { sapou }\end{array}$ \\
\hline
\end{tabular}

Berkaitan dengan hal tersebut keyakinan terhadap sesama makhluk yang berjiwa dan memiliki roh maka penting bagi orang Mentawai dalam wujud aktifitasnya selalu meminta izin kepada makhluk hidup dan makhluk mati dalam setiap elemen dunia purimanuaijat. Begitu juga dengan keyakinan orang Mentawai bahwa setiap makhluk hidup dan makhluk mati yang memiliki roh, penting juga untuk meminta izin, menghormati, dan berhubungan dengan roh-roh dan penguasa roh saikamanua, saikaporak, saikaoinan, dan diakhiri dengan hubungan saikaleleu yang berada di dunia sabulungan. Maka dari itu puliaijat akan ditutup dengan berburu adapun mengenai perburuan peneliti mendapatkan pengetahuan masyarakat mengenai kategori lingkungan orang Mentawai mengenai hutan, flora dan fauna.
Penulis mencoba menjelaskan bahwa masyarakat Buttui dan Tepu' mengenal ketegori tanah dan hutan, hal inilah yang menjelaskan bagaimana mereka memanfaatkan hutan dan isinya. Penting bagi peneliti memahami pengetahuan masyarakat mengenai ekosistem hutan itu sendiri, dikarenakan di dalam pengkategorian tersebut peneliti dapat memahami apa, kenapa dan bagaimana ekosistem hutan bagi orang Mentawai. Sehingga dapat menggambarkan etnoekologi primata demi mendapatkan pemahaman mengenai gambaran bagaimana primata itu sendiri hidup dalam pengetahuan masyarakat Buttui dan Tepu'. Sehingga primata tersebut menjadi penting dalam keseimbangan alam, sosial dan budaya di Mentawai.

Tabel 2. Etno-ekologi Hutan

\begin{tabular}{|c|c|c|c|c|c|}
\hline \multirow[t]{2}{*}{ No } & \multirow[t]{2}{*}{ Penamaan } & \multirow{2}{*}{$\begin{array}{l}\text { Ketinggian, } \\
\text { Lokasi, Jenis } \\
\text { Tanah dan } \\
\text { Kepemilikan }\end{array}$} & \multicolumn{2}{|c|}{ Jenis Tanaman dan Hewan } & \multirow[t]{2}{*}{ Fungsinya } \\
\hline & & & $\begin{array}{c}\text { Nama Lokal/Bahasa } \\
\text { Indonesia }\end{array}$ & Nama Ilmiah & \\
\hline 1 & $\begin{array}{l}\text { Uma dengan } \\
\text { Pangurep Iba }\end{array}$ & $\begin{array}{c}\text { 0-50 (tanah } \\
\text { datar } \\
\text { (massaba), } \\
\text { rawa (onaja) } \\
\text { dan sungai), } \\
\text { tanah } \\
\text { komunal, milik } \\
\text { komunal }\end{array}$ & $\begin{array}{l}\text { Pangurep Sagu, } \\
\text { pangurep gettek } \\
\text { (keladi), pangurep } \\
\text { magok (pisang), } \\
\text { pangurep kole (tebu), } \\
\text { pangurep toitet } \\
\text { (kelapa), okbuk, } \\
\text { mangeyak (bambu), } \\
\text { siloinan, salaloinan } \\
\text { (udang), lojo (belut) } \\
\text { toulu (labi-labi), dan } \\
\text { ikan (laitak) }\end{array}$ & $\begin{array}{l}\text { Mtroxylon sagu, } \\
\text { Mtroxylon } \\
\text { rumphii } \\
\text { Colocasia spp, } \\
\text { Rhnchoporus } \\
\text { ferrugineus, } \\
\text { Deris elipptica, } \\
\text { Antiaris } \\
\text { toxicaria, } \\
\text { Capsicum sp. }\end{array}$ & $\begin{array}{l}\text { Puliaijat dan } \\
\text { iba (pusat } \\
\text { kehidupan } \\
\text { manusia dan } \\
\text { kebutuhan } \\
\text { pokok } \\
\text { sehari-hari) }\end{array}$ \\
\hline
\end{tabular}




\begin{tabular}{|c|c|c|c|c|c|}
\hline 2 & $\begin{array}{l}\text { Pumonean } \\
\text { Saina }\end{array}$ & $\begin{array}{l}50-100 \text { (tanah } \\
\text { hitam), tanah } \\
\text { komunal, milik } \\
\text { individual } \\
\text { (leleu siboitok) }\end{array}$ & $\begin{array}{l}\text { Saina (babi), gougou } \\
\text { (ayam) dan pangurep } \\
\text { laggek }\end{array}$ & & $\begin{array}{l}\text { Pulijat, ala' } \\
\text { toga, iba dan } \\
\text { status sosial }\end{array}$ \\
\hline 3 & $\begin{array}{l}\text { Pumonean } \\
\text { leleu }\end{array}$ & $\begin{array}{c}100-150 \\
\text { (tanah } \\
\text { kuning), tanah } \\
\text { komunal, milik } \\
\text { komunal (leleu } \\
\text { maubak aku } \\
\text { tongok) }\end{array}$ & $\begin{array}{l}\text { Durian (dengan tiga } \\
\text { jenis; doriat, } \\
\text { mone/pusinoso, } \\
\text { toktuk, bababet } \\
\text { (rambutan hutan), } \\
\text { rarabit, siamung } \\
\text { (langsat), paggu } \\
\text { (mangga Mentawai), } \\
\text { peigu (cempedak } \\
\text { hutan), elegmata } \\
\text { ailulupa (jambu bol), } \\
\text { manau, poula, } \\
\text { ariribuk, bebeget, } \\
\text { laipat se'se', bere, } \\
\text { latso, bambu (dengan } \\
\text { tiga jenis mangeyak, } \\
\text { toktuk, metuk), } \\
\text { simoitet, katuka } \\
\text { meranti), pohon } \\
\text { kairitgi, katalaksoi, } \\
\text { biritzo, toroksat dan } \\
\text { paktara. Sebenarnya } \\
\text { dalam penyebutan } \\
\text { biasa sehar-hari } \\
\text { pumonean mone juga } \\
\text { disebut dengan } \\
\text { pumonean leleu, } \\
\text { dikarenakan } \\
\text { tempatnya berada di } \\
\text { leleu }\end{array}$ & $\begin{array}{l}\text { Durio zibhetinus, } \\
\text { Mangifera sp, } \\
\text { Durio sp, } \\
\text { Lappaceum spp, } \\
\text { atau Artocarpus } \\
\text { cryophyllum, } \\
\text { Radermachera } \\
\text { gigantea, } \\
\text { Calamus } \\
\text { manan, } \\
\text { Oncosperma sp, } \\
\text { Daemonorops } \\
\text { spp/calamus sp }\end{array}$ & $\begin{array}{l}\text { Puliaijat, ala' } \\
\text { toga, iba dan } \\
\text { status sosial }\end{array}$ \\
\hline 4 & Leleu & $\begin{array}{c}150-384 \\
\text { (tanah } \\
\text { kemerah- } \\
\text { merahan/liat), } \\
\text { tanah komunal } \\
\text { milik komunal }\end{array}$ & $\begin{array}{l}\text { Berbagai jenis batang } \\
\text { besar (batag sibeuga } \\
\text { seperti mincimin, } \\
\text { katuka toleat), batang } \\
\text { duri (ariribuk, } \\
\text { alalatek, labi, } \\
\text { bebeget, poula), dan } \\
\text { berbagai jenis } \\
\text { hewan-hewan buruan } \\
\text { bilou, joja, bokkoi, } \\
\text { simakobu, simaliak, } \\
\text { sibeutubu, sirukut, } \\
\text { sabirut, saina leleu) } \\
\text { dan berbagai jenis } \\
\text { hewan yang tidak } \\
\text { diburu }\end{array}$ & $\begin{array}{l}\text { (Batang sibeuga } \\
\text { Diptrocarpus, } \\
\text { shorea, ficus sp, } \\
\text { Swintonia sp, ) } \\
\text { batang duri } \\
\text { Arenga } \\
\text { obtusifolia, } \\
\text { Daemonorops } \\
\text { sp, Arenga } \\
\text { pinnata), } \\
\text { baccaurea } \\
\text { sumatrana, } \\
\text { Campnosperma } \\
\text { auriculata, } \\
\text { Batang buah } \\
\text { Flacourtia } \\
\text { rukam, Hewan } \\
\text { buruan Sus } \\
\text { cristatus, } \\
\text { Presbythis } \\
\text { potenzian, } \\
\text { Simias cancolor, } \\
\text { Hylobates } \\
\text { klossi, Macaca } \\
\text { siberu) }\end{array}$ & $\begin{array}{l}\text { Pulijat, iba, } \\
\text { status sosial, } \\
\text { tempat } \\
\text { sakral } \\
\text { (tinggalnya } \\
\text { para roh-roh } \\
\text { nenek } \\
\text { moyang dan } \\
\text { saikamanua) }\end{array}$ \\
\hline
\end{tabular}



Dari kategorisasi hutan tersebut hewan buruan baik itu joja, bokkoi, simakobu, bilou, sileu'leu, saina leu'leu merupakan hewan peliharaan dan tempat sakral roh nenek moyang mereka yang juga tinggal di leleu. Adapun yang membedakan diantara leleu lainya atau leleu siboitok (pumonean) dengan ungkapan orang Mentawai menurut Aman Raiba bahwa leleu merupakan tempat bagi kami untuk berburu dan mengambil kayu dalam pembuatan abag dan uma (akek iba). Walaupun leleu yang rendah disebut juga sebagai leleu, namun leleu yang terkhusus untuk buruan "masipanah siloghui mui ka pata (ka leleu), misalkan tak moilek ekeu ecak siloghui mui tak moilek sampei ka pata barati nia leleu sabeuga nanek yang berartinia leleu, oto ekeu masipanah silghui mui ka pata tapoi tak moilek ekeu ecak barati nia tak leleu (panahkan panahmu ke atas leleu, misalkan kamu tidak bisa melihat panahmu dan panahmu tidak bisa sampai ke atasnya itu lah yang namanya leleu, sedangkan jika kamu memanah panahmu ke atas tapi kamu bisa lihat panahmu dan panahmu sampai ke atas berarti itu bukanlah sebuah leleu)". Adapun untuk penjelasan hewan buruan dapat dilihat pada tabel 3 dibawah ini.

Tabel 3. Klasifikasi Primata Endmik di Pulau Siberut

\begin{tabular}{|c|c|c|c|c|c|c|}
\hline No & $\begin{array}{l}\text { Nama } \\
\text { Primata }\end{array}$ & Ciri-Ciri Tubuh & $\begin{array}{c}\text { Jumlah } \\
\text { Kelompok } \\
\text { ketika } \\
\text { Perburuan }\end{array}$ & $\begin{array}{c}\text { Kehidupan dan } \\
\text { Makanan }\end{array}$ & Suara & Perburuan \\
\hline 1 & $\begin{array}{l}\text { Joja } \\
\text { (Prebitis } \\
\text { Potenzian } \\
\text { i) }\end{array}$ & $\begin{array}{l}\text { Berekor } \\
\text { panjang (sipaik- } \\
\text { paik) dan } \\
\text { berwarna hitam, } \\
\text { kuning dan } \\
\text { putih } \\
\text { (simakokot, } \\
\text { kinieu dan } \\
\text { simabulau) }\end{array}$ & $3-5$ & $\begin{array}{l}\text { Pohon, Daun } \\
\text { dan Buah- } \\
\text { buahan }\end{array}$ & $\begin{array}{c}\text { Sipujag } \\
o \\
\text { (mako- } \\
\text { mako) }\end{array}$ & $\begin{array}{l}\text { Boleh } \\
\text { diburu, jika } \\
\text { berwarna } \\
\text { putih dan } \\
\text { joja } \\
\text { perempuan } \\
\text { tidak boleh } \\
\text { diburu } \\
\text { (mitologi dan } \\
\text { pantangan } \\
\text { kerel) }\end{array}$ \\
\hline 2 & $\begin{array}{l}\text { Simakobu } \\
\text { (Simias } \\
\text { Cancolor) }\end{array}$ & $\begin{array}{l}\text { Berekor sedang } \\
\text { (sipaik-paik) } \\
\text { dan berwarna } \\
\text { hitam } \\
\text { (simakotkot) }\end{array}$ & $4-6$ & $\begin{array}{l}\text { Pohon, daun } \\
\text { dan Buah- } \\
\text { buahan }\end{array}$ & $\begin{array}{l}\text { Sipuag } \\
\text { ak } \\
\text { (gak- } \\
\text { gak) }\end{array}$ & $\begin{array}{l}\text { Boleh di } \\
\text { buru }\end{array}$ \\
\hline 3 & $\begin{array}{l}\text { Bokkoi } \\
\text { (Macaca } \\
\text { Siberu) }\end{array}$ & $\begin{array}{l}\text { Berekor pendek } \\
\text { (sipaik-paik) } \\
\text { dan berwarna } \\
\text { kemerah- } \\
\text { merahan } \\
\text { (simabo) }\end{array}$ & $20-50$ & $\begin{array}{l}\text { Pohon, Tanah } \\
\text { dan Sungai } \\
\text { (pohon, buah } \\
\text { dan surapik) }\end{array}$ & $\begin{array}{l}\text { Sipuhih } \\
\text { i(hihi) }\end{array}$ & Boleh diburu \\
\hline 4 & $\begin{array}{l}\text { Bilou } \\
\text { (Hylobate } \\
\text { s klossi) }\end{array}$ & $\begin{array}{l}\text { Tidak berekor } \\
\text { dan berwarna } \\
\text { htam } \\
\text { (simakotkot), } \\
\text { terkadang } \\
\text { berwarna putih } \\
\text { (simabulau) }\end{array}$ & $4-9$ & $\begin{array}{l}\text { Pohon, daun } \\
\text { dan buah- } \\
\text { buahan }\end{array}$ & $\begin{array}{l}\text { Sipuko } \\
\text { waik } \\
\text { (owaik- } \\
\text { owaik) }\end{array}$ & $\begin{array}{l}\text { Tidak boleh } \\
\text { diburu dan } \\
\text { pantangan } \\
\text { kerei, hanya } \\
\text { anak muda } \\
\text { yang boleh } \\
\text { memburu } \\
\text { namun pada } \\
\text { waktu } \\
\text { tertentu saja }\end{array}$ \\
\hline
\end{tabular}

Dari ketegorisasi tersebut, untuk perburan hanya suara, bentuk tubuh, dan jejak menjadi cara orang Mentawai dalam berburu. Selain itu juga ada musim yang mana 4 primata ini akan turun ke ladang masyarakat. Untuk itu penulis akan menjelaskan hubugan ute' simagere terhadap dunia purimanuaijat dalam lingkungan alam dan sosial, dan hubungan sabulungan dalam lingkungan sosial dan 
budaya masyarakat Mentawai. Adapun penjelasan tersebut akan dijelaskan sebagai berikut.

1. Ute' Simagere: Penyeimbang Dunia Purimanauijat (Lingkungan Alam dan Sosial)

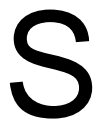
istem kepercayaan yang tertuang dalam mitologi masyarakat Buttui dan Tepu' (pumumuan) menceritakan bagaimana cara mereka berladang sagu, keladi dan pisang, beternak dan berburu dari dulu hingga sekarang. Mitologi itu dijaga bahkan ribuan tahun yang lalu dan diceritakan sehingga dapat hidup dalam kehidupan masyarakat di Pulaggajat Buttui dan Tepu' hingga saat ini. Maka dari itu mitologi tersebut terlihat dalam aktifitas mereka yang pergi ke sungai, hutan dan leleu untuk memenuhi keberlangsungan hidup mereka dan demi menjaga hubungan antara sesama mereka, sesama suku lain, sesama makhluk lain baik itu makhluk hidup maupun makhluk mati, inilah yang disebut dengan dunia purimanuaiajat. Namun tidak hanya sebatas itu hubungan itu juga mengatur hubungan sesama makhluk gaib atau yang mereka sebut dengan dunia sabulungan yang akan dijelaskan nantinya. Adapun hubungan sebagai makhluk yang memiliki jiwa (simagere) dan roh (ketcat) tersebut diatur dalam kehidupan yang subsisten orang Mentawai, sebagaimana penulis sebut bahwa orang Mentawai adalah orang penjelajah lembah (leleu). Menjadi orang lembah atau orang yang hidup dengan hutan, kesaharian mereka habiskan dengan hidup di hutan, membuat uma, sampan (abag), menangkap ikan (pamabili) di sungai, bercocok tanam sagu dan keladi, berladang (pumonean mone), berternak (pumonean saina), berburu (rou-rou) di leleu. Hampir semua aktifitas mereka dihabiskan di sungai (batoinan), hutan (se'se), dan leleu (leleu). Maka dari itu orang Mentawai lebih dianggap sebagai orang asli penjelajah hutan/leleu dengan kebudayan Arat Sabulungan-nya.

Kesadaran mereka sebagai makhluk yang memiliki jiwa dan roh, maka ketika mereka masih dalam kandungan dan menjadi anak-anak hubungan tersebut sudah disadari bahwa pentingnya akan hal jiwa dan roh. Agar jiwa mereka dikenal oleh jiwa dan roh dari makhluk lain. Maka dari itu hal tersebut terlihat dari ketika mereka dilahirkan, baik itu perempuan dan laki-laki akan di punen-kan terlebih dahulu. Salah satu punen yang sangat penting dalam pintu gerbang bagi orang Mentawai yang menghubungkan mereka dengan dunia purimanuaijat dan sabulungan adalah punen eneget atau punen sogunei. Punen inilah harapan mereka agar jiwa mereka nantinya dapat mengenal jiwa dan roh yang berada di dunia purimanuaijat dan sabulungan. Sehingga mereka dapat pergi berburu, menangkap ikan di sungai, pergi ke leleu, dan membuat ladang. Maka dari itu sejak kecil laki-laki dan perempuan di Mentawai sudah pandai pergi ke sungai, hutan dan leleu. Anak perempuan yang pandai mencari kayu bakar, menangkap ikan di sungai, bercocok tanam keladi. Sedangkan laki-laki sejak kecil sudah pandai menanam sagu dan kelapa, memelihara ayam dan babi, bahkan mereka sudah turut membantu dalam membuat uma dan abag. Setelah mereka dewasa, anak laki-laki sudah tidak tinggal di uma lagi, melainkan dia akan diberikan sejumlah tanah untuk membuat ladang dan membuat sapou nya sendiri. Dengan memelihara babi dan ayam yang diberikan kedua orang tuanya, hingga babi dan ayam tersebut menjadi besar dan semakin banyak. Namun semua tersebut butuh kerja keras dari seorang anak laki-laki, dikarenakan semua tersebut dilakukannya untuk memenuhi kebutuhan hidup dan kebutuhan kelak untuk menikah, dikarenakan untuk menikah perlu menyediakan banyak babi (ala' togha). Sedangkan berbeda dengan perempuan, perempuan hanya menunggu lamaran dari seorang laki-laki. Tetapi perempuan Mentawai haruslah kuat yang mana perempuan kuat disukai lelaki Mentawai, kuat dalam mencari makan untuk kebutuhan sehari-hari, kuat dalam mengurus rumah tangga dan kuat dalam fisik yang membantu suaminya dalam pekerjaan mengurus hartanya. Adapun semua mata pencaharian tersebut terdapat pembagian, dan nyatanya dalam pembagian mata pencaharian tersebut dilakukan secara bersama-sama. Ketika mereka layak untuk menikah, maka mereka akan memilih untuk mengikat satu sama lain dengan sesere dan meneruskan dengan pernikahan secara adat (punen putalimoghat). Begitu juga dengan manusia, ketika menikah jiwa mereka perlulah di kenalkan agar antara sesama makhluk yang 
memiliki simagere merasa senang dan tidak terjadi masalah. Maka dari itu mereka melakukan punen putalimoghat. Dari penjelasan ini maka penting bahwa sesama makhluk baik itu manusia, hewan, tumbuhan dalam dunia purimanuaijat penting dalam menjaga hubungan sesama makhluk yang memiliki simagere dan ketcat.

Semua yang dilakukan dalam akifitas sehari-hari mereka nyatanya mereka lakukan untuk memenuhi kebutuhan hidup mereka, baik itu suplai protein, status sosial kelompok mereka dan upacara nantinya. Adapun berkaitan dengan upacara, uma merupakan pusat bagi berkumpul satu sukunya. Ketika sikabukat uma sudah mengajak berkumpul satu suku mereka, sikabukat uma mulai menyalakan api di bat katerangat sapou (tungku api di tengah uma), para keluarga mulai berkumpul untuk membicarakan mengenai upacara. Upacara ini dilakukan dalam dua kondisi yaitu upacara untuk lingkaran kehidupan (life cycle) yang dikenal dengan punen dan upacara untuk keseimbangan yang dikenal dengan puliaijat. Namun disini peneliti akan membahas upacara yang ditutup dengan berburu saja atau upacara untuk keseimbangan (puliaijat). Tetapi tidak kemungkinan peneliti membicarakan tentang upacara yang tidak ditutup dengan berburu (punen), dikarenakan upacara yang tidak ditutup dengan beburu merupakan bagian untuk keseimbangan itu sendiri. Seperti halnya punen soguney yang merupakan upacara lingkaran kehidupan namun memerlukan aktifitas berburu. Adapun kapan dilakukan upacara yang ditutup dengan aktifitas berburu. Ketika mereka sadar bahwa kondisi jiwa dan roh dalam keadaan tidak seimabang antara dunia purimanuiajat dan sabulungan.

Adapun beberapa contoh mengenai puliaijat yang ditutup dengan berburu Seperti halnya puliaijat pasikud uma yang perlu memperbaiki/membuat uma baru (kud uma), memperkuat hubungan antar kerabat termasuk kerabat pernikahan, pembuatan sampan baru (kud abag), membuat ladang baru (tinung/u), dan perlunya mengenang arwah nenek moyang mereka (saukkui sabulungan) ataupun hubungan antar sesama makhluk yang memiliki jiwa (simagere) dan roh (ketcat). Maka mereka mulai sadar hubungan antara dunia nyata dan dunia supranatural perlu di seimbangkan melalui upacara yang diperantarai oleh kerei. Akibat aktifitas manusia yang memanfaatkan lingkungannya. Sehingga upacara disini sebagai mekanisme atau pengatur hubungan antara manusia dengan lingkungan alam, sosial dan budaya. Lalu seperti apa mekanismenya, upacara tidak bisa dilakukan ketika semua yang dibutuhkan belum tersedia. Ketika sikabukat uma telah mengumumkan akan mengadakan upacara, maka para keluarga atau masing-masing keluarga akan saling bergotong royong untuk menyediakan keperluan yang perlu disediakan untuk upacara nantinya. Upacara merupakan kewajiban orang Mentawai dalam menyediakan segala hal yang mencangkup kebutuhan upacara baik itu sagu, babi, ayam dan makanan lainnya. Sehingga kebudayaan berladang dan berternak merupakan bagian dari upacara. Didalam upacara, semua hasil ladang baik itu sagu, keladi, babi, ayam dalam satu keluarga saling bantu membatu untuk mengumpulkan makanan untuk persiapan upacara.

Biasanya mereka membutuhkan beberapa minggu atau beberapa bulan bahkan betahun-tahun untuk menyediakan keperluan puliaijat atau punen. Maka disini penting bagi keluarga memiliki banyak ladang sagu, keladi, kelapa, dan ternak babi dan ayam. ${ }^{6}$ Selain itu juga mereka harus mengumpulkan bambu, kayu bakar dan mencari ikan di sungai. Setelah diumumkan untuk upacara barulah keluarga yang pergi ke pumonean saina' untuk menginap disana dan membawa babinya untuk disumbangkan, atau ada juga yang menyagu bersama terkhusunya sikabukat uma. Inilah cara bagi masyarakat Butui dan Tepu' mendapatkan suplai protein tambahan dari hasil kerjanya memelihara babi yang hingga rata-rata babi dimiliki mencapai 70100 ekor babi atau memotong ayam namun tidak sebanyak babi yang mereka pelihara. Pada dasarnya jika dalam suatu keluarga terdapat 5 keluarga besar, terkadang hanya dua atau tiga keluarga yang

\footnotetext{
${ }^{6}$ Berkaitan kenapa, pentingnya makanan yang perlu disediakan dalam upacara, dikarenakan makanan inilah yang nantinya dimakan bersama dan makanan inilah juga yang akan disembahkan kepara Saikamanua dan roh-roh nenek moyang mereka.
} 
menyumbangkan babi, mereka menyumbangkan babi sampai 20 bahkan lebih untuk dipotong nantinya. Setelah mereka merasa sudah siap untuk melakuan upacara (puliaijat) barulah sikabukat uma akan mengundang satu suku mereka atau suku perpecahan dari suku mereka, kerabat perkawinan, tetangga, dan siripok. ${ }^{7}$

Barulah bagunan ${ }^{8}$ dibuat bersamasama, pertanda undangan untuk roh-roh langit dan Saikamanua untuk menghadiri puliaijat. Selain itu juga untuk melindungi dari roh-roh jahat. Pada puliaijat inilah kerja sama antara keluarga satu suku menjadi penting kembali, baik tugas seorang laki-laki (simateu), perempuan (sinanalep), sikabukat uma, sirimata, maman, sikelabai, dan anakanak kecil (togha) bahkan undangan. Ketika upacara dimulai semua mulai berpantangan (mukeikei) baik itu keluarga maupun orang yang diundang, terkhusus pantangan yang sangat berat adalah sikabukat uma, orang yang nantinya akan mengatur dalam keberlangsungan upacara seperti halnya dia harus berpuasa sedangkan yang lainnya tidak. Sebelum upacara pun dimulai ketakutan akan roh-roh jahat, hampir disetiap puliaijat atau punen, selalu diberikan tanda baik itu berupa daun, kepada jiwa yang masih hidup agar tidak lupa dengan jiwanya ketika upacara telah selesai.

Berkaitan dengan pembagian kerja dalam upacara, jika perempuan asik membuat sagu dan keladi menjadi makanan. Sedangkan laki-laki akan memulai upacara dengan memotong babi dan ayam, disinilah peran sikerei menjadi penting hingga proses upacara selesai. Pengetahuan dan kemampuan sikerei melihat dunia sabulungan, dan pengetahuan sikerei yang mampu menghubungkan dunia nyata dengan dunia sabulungan melalui nyayian-nyayian (urai) dan sumpah (suppah) dengan diperantarai daun-daunan (bulungan) dan media perantara lainnya. Urai dan suppah inilah yang berisi harapan, rayuan, bujukan, ucapan terimakasih, dan mempunyai makna-makna lainya. Adapun

\footnotetext{
${ }^{7}$ Bagi yang tidak memiliki sikerei mereka juga akan mengundang sikerei dari suku lain untuk membantu.

${ }^{8}$ Bagunan merupakan bambu yang diatasnya akan dibuat umat simagere (mainan bagi roh atau burung manyang) dan diletakan di depan uma.
}

sikerei selalu menggunakan daun-daunan sebagai media prantara untuk memanggil, membujuk, melindungi dan mengusir para roh-roh yang berada di dunia sabulungan. Adapun selepas upacara, daun-daun ini pun tidak melainkan dibuang. Namun disimpan di bakkat katsaila, suatu tempat berkumpulnya jiwa dan roh yang masih hidup, dan juga sebagai tempat datanganya roh-roh yang sudah meninggal (saukkui).

Adapun berbagai upacara berfungsi sebagai pengatur hubungan antara manusia dan roh-roh yang ada di dunia supranatural. Dibuktikan dengan kerei selaku dukun yang dapat memanggil roh-roh yang sudah meninggal baik itu nenek moyang dan rohroh penjaga alam supranatural. Untuk memberikan persembahan berupa babi yang sebelumnya mereka pelihara dan berharap jiwa dari babi tersebut dapat memaafkanya dan roh dunia supranatural dapat mengizinkan upacaranya. Begitu juga dengan pembuatan uma, abag, dan pumonean upacara dilakukan kembali, dengan memberikan sejumlah makanan agar dunia supranatural tidak marah kembali. Ketakutan akan jiwa inilah yang melatarbarbelakangi pentingnya upacara pada masyarakat Mentawai, agar hubungan manusia dapat terjaga dengan dunia supranatural. Inilah dalam kondisi upacara sebagai mekanisme penyeimbang lingkungan budaya. Dimana sistem kepercayaan Arat Sabulungan untuk mengatur segala kehidupan orang Mentawai. Terlihat dalam upacara tersebut, ternyata semua makanan yang telah disediakan akan diberikan kepada keluarga satu suku, kerabat karena pernikahan, teman dekat, undangan dan juga akan disembahkan kepada roh-roh nenek moyang mereka yang telah meninggal serta penguasa alam. Pemberian babi ini atau disebut dengan otchai ini, tidak hanya diberikan kepada keluarga luasnya saja, namun juga antar suku yang telah memberikan babi kepada mereka sebelumnya. Ini merupakan cara bagaimana orang Mentawai menjaga hubungan antara sesama mereka terhadap lingkungan sosial yang mereka tinggali dan ini merupakan salah satu cara bagi orang Mentawai untuk mendapatkan suplai protein yang berlebih. Terlihat dibalik upacara tersebut hanyalah sedikit yang dimakan dari pemotongan babi sebanyak 20-50 babi atau pemotongan 
ayam berserta sejumlah makanan lainya. Melainkan semua makanan tersebut akan dimakan sedikit dan lebih banyak disimpan dengan bambu yang nantinya dapat dimakan untuk setiap keluarganya dalam memenuhi kebutuhan sehari-hari. Dari paparan diatas adapun upacara tersebut dengan pemotongan beberapa hewan peliharaan yang kemudian dibagikan kepada suku mereka, tetangga mereka, roh nenek moyang mereka dan disembahkan kepada roh langit (saikamanua). Setelah melakukan upacara, dalam kondisi upacara puliaijat. Maka puliaijat akan ditutup dengan berburu, merupakan mekanisme orang Mentawai dalam mengatur keseimbangan sosial dan budaya di Mentawai yang akan dijelaskan pada bagian dibawah ini.

2. Ute' Simagere: Penyeimbang Dunia Sabulungan (Lingkungan Sosial dan Budaya)

U pacara (puliaijat), wujud keseimbangan yang terakhir adalah hubungan antara elemen saikaleleu/Si Bara Ka Leleu, ketika hubungan antara sesama mereka, sesama roh-roh nenek moyang mereka yang berada di langit (saikamanua) ataupun di sungai (Saikaoinan), dan di bumi (Si Bara Ka Porak/Si Bara Ka Baga). Hubungan tersebut belum berakhir dikarenakan kenyataanya kebanyakan aktifitas mereka yang selalu pergi ke leleu. Maka mereka juga harus berhubungan dengan roh-roh nenek moyang mereka di leleu dengan cara melakukan perburuan, maka dari itu upacara akan diakhiri dengan berburu, sekaligus menutup rangkaian dari upacara dengan pembagian hasil buruan dan pembuatan ute' simagere.

Berkaitan dengan penjelasan diatas, ternyata tidak hanya menyangkut hubungan yang secara nampak saja, nyatanya mereka tidak hanya memikirkan kebutuhan akan jiwa yang masih hidup, tetapi mereka juga memikirkan roh-roh nenek moyang mereka dan roh hewan yang sudah disembelih tadi. Maka dari itu otchai tersebut akan disembahkan kepada roh-roh yang sudah mati baik itu nenek moyang mereka dan penguasa alam yaitu Saikamanua. Maka disinilah peran kerei dalam memanggil para roh nenek moyang dan penguasa alam untuk menerima persembahan mereka agar nantinya mereka dapat melindungi mereka dan mengizinkan mereka kembali untuk beraktifitas. Maka dari itu hubungan sosial tidak hanya menyangkut hal yang nampak saja, namun jiwa yang sudah mati penting untuk menjaga hubungan sosial antara rohroh nenek moyang mereka dengan adanya pembuatan ute' simagere.

Setelah pembagian makanan pada bakkat katsaila, jiwa yang masih hidup, para roh leluhur dan penguasa Saikamanua. Begitu juga dengan tengkorak babi yang telah disembelih yang disebut mereka dengan ute' saina', tengkorak babi tersebut tidak akan dibuang melainkan akan di gantung di depan uma yang berhadapan dengan uma. Hal ini menandakan agar babibabi mereka yang masih hidup dapat senang dan tumbuh besar. Adapun selain itu juga mereka menghormati roh hewan tersebut, dengan membuat mainan bagi roh yaitu umat simagere atau burung manyang. Namun disini umat simagere berfungsi sebagai mainan bagi roh-roh yang masih hidup dan mati di dalam uma yang nyatanya sesama makhluk yang berjiwa sama-sama senang dengan mainan (bandingkan Schefold, 1991). Adapun wujud penghormatan terakhir adalah dengan pembuatan ute' simagere, ute' simagere ini akan dibuat secara bersama-sama diakhir dalam proses upacara. Pada malam sebelum mereka pergi berburu dan membuat ute' simagere mereka akan memanggil kembali roh-roh nenek moyang mereka dengan melakukan turuk laggai, tarian turuk laggai ini menyatu dengan rohroh alam terlihat dengan gerakan-gerakan yang ditampilkan dengan meniru hewanhewan yang berada di lingkungan dunia nyata seperti bilou, gou-gou' bahkan terkadang mempelihatkan adegan bertarung. Pada tarian ini penari seakanakan berhubungan dengan dunia sabulungan dan seakan-akan melihat para roh. Pada waktu tertentu, mereka akan kerasukan yang manandakan roh-roh nenek moyang mereka masuk kedalam tubuh mereka.

Berulah upacara akan ditutup dengan rangkaian aktifitas berburu. Adapun perburuan ini dilakukan berdasarkan pemaparan peneliti sebelumnya dan suppah kerei yang mana setiap unsur dunia purimanuaijat dan dunia sabulungan harus dalam keadaan seimbang. Jika salah satu hubungan tersebut terganggu maka dapat 
mengganggu hubungan lainya. Maka dari itu tidak hanya sebatas hubungan antara sesama keluarga mereka, hubungan antara roh yang masih hidup dengan roh yang sudah meninggal, dan hubungan manusia dengan penguasa alam Saikamanua. Namun setiap hubungan tersebut harus dalam keadaan seimbang, dikarenakan kehidupan mereka yang selalu dihabiskan dengan pergi ke sungai, hutan dan leleu. Jiwa dan roh mereka juga terhubung dengan roh sungai, hutan dan leleu. Begitu juga dengan penguasa sungai, hutan, dan leleu mengenal jiwa dan roh mereka. Dikarenakan ketika mereka lahir saja, mereka sudah dikenalkan dengan jiwa dan roh mereka dengan roh sungai, hutan, dan leleu dengan melakukan punen eneget atau sogunen. Maka dari itu dari punen inilah yang menjadi gerbang bagi mereka dapat berhubungan degan dunia sabulungan terkhusunya Saikaoinan, Si Bara Ka Baga, dan Si Bara Ka Leleu. Karena permasalahanya bahwa etnis Mentawai yang memanfaatkan lingkungannya seperti membuat uma, abag atau membuka ladang baru yang membuat tergangunya keseimbangan akan jiwa dan roh tersebut. Maka dari itu upacara dilakukan, karena mereka harus meminta izin kembali, agar mendapatkan izin tersebut maka upacara akan diakhiri dengan pergi berburu. Dikarenakan persembahan yang dilakukan untuk roh-roh nenek moyang saja tidak cukup dan roh-roh langit. Tetapi penting juga bagi mereka mempersembahkan makanan mereka kepada roh penjaga hutan dan leleu.

Adapun berburu dilakukan untuk berdialog dengan roh Si Bara Ka Leleu dengan melakukan peburuan. Maka dari itu sebelum melakukan perburuan, mereka akan mempersembahkan ayam terhadap tengkorak monyet yang didapatkan sebelumnya baik didapatkan pada upacara pertama mereka atau didapatkan dari upacara eneget yang mereka sebut dengan punen simatei ketcat. Tengkorak hasil buruan inilah yang disebut dengan ute simagere. Ute' simagere ini terdiri dari tengkorak babi leleu, beberapa jenis monyet seperti bilou, joja, bokkoi, simakobu dan rusa yang akan digantungkan di tengah uma dan menghadap keluar atau ke arah sungai, hutan dan leleu. Penggantungan ini bertujuan agar nantinya ketika berburu si pemburu dapat dengan mudah mendapatkan hewan buruan dengan cara melakukan punen simatei ketcat. Punen simatei ketcat ini dilakukan agar nantinya roh leleu dapat mematikan roh hewan buruan mereka sesuai dengan namanya simatei ketcat (mematikan roh). Sehingga mereka mendapatkan hewan buruan dan mengizinkan mereka dapat mengambil hewan buruan tersebut. Selain itu juga tengkorak dari monyet tersebut akan memanggil temanya untuk bersama mereka dikarenakan mereka senang berada di uma. 9 Namun tidak lah demikian, penggantungan tengkorak hewan buruan (ute' simagere) ini dilakukan dikarenakan menghormati roh-roh leluhur mereka dan penguasa sungai, hutan dan leleu, karena hewan ini merupakan hewan peliharahan mereka. Maka dari itu kepala tengkorak dihadapkan ke arah sungai, hutan dan leleu. ${ }^{10}$ Dilain hal pembuatan ute' simagere juga merupakan keyakinan mereka bahwa keseimbangan tersebut tidak hanya keseimbangan terhadap jiwa yang masih hidup, nyatanya jiwa yang sudah matipun masih dalam keadaan hidup, terlihat tengkorak yang digantungkan menjadi ute' simagere, bahwa tengkorak tersebut masih memiliki jiwa dan dapat memanggil temannya. Mereka meyakini jiwa dari primata ketika mereka di buru dan mati, melainkan tidak lah mati jiwa dan roh tersebut, nyatanya mereka masih hidup dalam tengkorak primata tersebut yaitu ute' simagere yaitu tengkorak yang berjiwa yang

\footnotetext{
${ }^{9}$ Maka dari itu tengkorak tersebut akan dihiasi dengan berbagai manai, buluat dan umat simagere.

${ }^{10}$ Hampir setiap uma memiliki banyak tengkorak terihitung pada Suku Salakirat sebanyak primata 203, babi dan rusa 100 , ular 10 , buaya 1 dan burung 20. Untuk Suku Sabetiliakek Primata 177, dan Suku Sakuddei primata sebanyak 223. Namun biasanya tengkorak tersebut sudah dikumpulkan sejak rumah tersebut didirikan ada yang uma berumur 70 tahun atau uma yang didapatkan dari generasi ke 3 keturunan nenek mereka (punuteteu). Jika dibandingkan dengan uma yang baru terlihat tidak banyak tenkorak yang tergantung. Adapun jika mereka membuat uma baru, maka tengkorak tersebut akan dipindahkan. Tengkorak yang banyak menandakan status sosial uma tersebut, bahwa suku tersebut rajin berburu.
} 
dapat memanggil temanya di leleu. Maka dari itu ute' simagere merupakan cultural core masyarakat Mentawai.

Berkaitan dengan pertanda keberhasilan berburu bagi mereka ketika mereka mendapatkan hewan buruan maka penguasa leleu (Si Bara Ka Leleu) telah mengizinkan upacara mereka dan mereka dapat beraktifitas seperti biasanya. Maka dari itu mereka biasanya akan menghabiskan waktu hingga seminggu dalam berburu. Namun terkadang mereka juga tidak mendapatkan hewan buruan, karena kondisi cuaca. Namun yang terpenting bagi mereka dapat atau tidak dapat hewan buruan. Mereka sudah pergi melakukan perburuan, dan pulang dengan selamat. Maka hal tersebut menandakan Si Bara Ka Leleu sudah mengizinkan mereka untuk beraktifitas seperti biasanya.

Dibalik hal perburuan, hubungan tersebut tidak hanya mengatur antara dunia sabulungan tetapi ketika mereka mendapatkan hewan buruan, nyatanya hewan buruan tersebut tidaklah dimakan bersama. Jika dalam upacara babi, ayam dan makanan lainya dimakan bersama, namun tidak dengan hewan hasil buruan. Hewan hasil buruan akan langsung dibagikan, namun tidak hanya orang yang hadir atau orang yang pernah memberikan babi. Setelah konflik sementara terjadi antar suku ${ }^{11}$ akibat tuddukat berbunyi yang membuat suku lain ingin menyainginya. Namun konflik itu akan berhenti, ketika suku yang mendapatkan hewan buruan tersebut akan membagikan setiap suku di pulaggajat mereka. Sehingga suku yang diberikan tersebut akan membalas kembali ketika mereka mendapatkan hewan buruan. Maka dari itu hubungan sosial antar suku di pulaggajat mereka tetap terjaga. Namun nyatanya pemberian otchai buruan, sebenarnya bukanlah yang terpenting siapa yang mendapatkan buruan/siapa yang telah mendapatkan hasil yang paling banyak ketika berburu. Namun bukanlah itu maksudnya, perburuan dan pemberian otchai buruan tidaklah untuk status sosial peribadi, namun yang terpenting bagi orang Mentawai adalah status sosial kelompok mereka.

Lalu beberapa penelitian mengatakan perburuan di Mentawai yang

\footnotetext{
${ }^{11} \mathrm{Hal}$ ini berbeda engan priode $p a k o$

82 | P a g e
}

menyebabkan kepunahan, padahal jika mengikuti sistem kepercayaan Arat Sabulungan yang tidak hanya mengatur hubungan sosial, budaya namun juga mengatur hubungan manusia dengan alamnya baik yang nyata maupun yang tidak nyata. Untuk menjawab hal tersebut peneliti menggunakan pendekatan etno-ekologi. Adapun peneliti membagi beberapa upacara dan juga membagi beberapa ketegori tentang lingkungan alam baik itu tanah, hutan, dan primata yang nyatanya membantu peneliti dalam menjelaskan hubungan masyarakat Mentawai dengan lingkunganya tekhususnya dengan primata.

Jika sistem kepercayaan Arat Sabulungan yang mengatur bahwa pentinganya bagi masyarakat Mentawai untuk memiliki uma, abag, ladang sagu, keladi, kelapa, buah-buahan (pumonean mone), dan ternak babi (pumonean saina). Begitu juga dengan pentingnya etnis Mentawai memiliki kerei, ataupun pentinganya masayarakat Mentawai untuk melakuan upacara pashipiat shot, mutiti', putlimoghat, simamatei, saukkui sabulunga, kud uma, kud abag, dan lain-lain. Hal lainnya penting juga bagi orang Mentawai melakukan perburuan. Semua itu dilakukan untuk mengatur hubungan mereka dengan lingkungan alam, sosial dan budaya.

Berkaitan dengan perburuan, primata di Mentawai secara garis besar tidak ada pada rantai makanan. Maka wajar saja manusia sebagai predator alami untuk mengatur keseimbangan ekosistem jumlah primata tersebut. Dengan melakukan perburuan pada intesitas waktu tertentu saja. Sebagaimana peneliti mengkategorikan beberapa upacara dan juga mengkategorikan lingkungan alam di Mentawai seperti mengkategorkan tanah yang kemudian dari sanalah masyarakat Mentawai memiliki pengetahuan pengkategorian hutan, flora dan fauna yang mana akan dijelaskan secara mendalam satu persatu dibawah ini. Namun penjelasan tersebut memiliki kaitan satu sama lain.

Sebagaimana dalam setiap upacara masyarakat akan melakukan perburuan. Namun tidak lah semua upacara masyarakat Mentawai perlu melakukan perburuan. Hanya ada beberapa upacara yang perlu melakuan perburuan yaitu puliaijat. Puliaijat merupakan upacara yang disebabkan akibat jiwa dan roh pada keluarga mereka 
terancam, begitu juga dengan lingkungan alam teracam akibat aktifitas etnis Mentawai seperti membuka ladang (tinunglu), membuat uma besar (kud uma sibeuga), membuat abag (kud abag) dan mengenang para roh-roh nenek moyang mereka (saukkui sabulungan). Sehingga roh-roh nenek moyang mereka dan penguasa alam baik itu Saikamanua, Taikapolak, Saikaoinan dan Si Bara Ka Leleu marah dan dapat menyebabkan bencana. Berbeda dengan punen dan lia ${ }^{12}$, untuk punen dilakukan untuk melindungi jiwa dan roh yang masih hidup seperti dalam lingkaran kehidupan. Namun ada punen eneget yang mesti melaukakan perburuan, punen eneget merupakan gerbang bagi laki-laki Mentawai untuk berhubungan dengan roh hutan, sungai dan leleu, agar nantinya mereka dapat berladang, menangkap ikan, ke leleu, dan berburu.

Berkaitan dengan perburuan dilakukan oleh masyarakat Mentawai di leleu. Adapun berdasarkan pengkategorian peneliti, keempat primata tersebut berdasarkan pengatahuan masyarakat Mentawai hidup di leleu. Maka dari itu masyarakat Mentawai melakuan perburuan di leleu, yang membutuhkan berapa hari hingga seminggu untuk berburu. Tidak lah lain pengetahuan masyarakat tentang hutan dengan pembagian wilayah ini dapat menjelaskan ekosistem di Mentawai itu sendiri dan menjelaskan kaitan manusia dengan kehidupan purimanuaijat dan sabulungan. Adapun masyarakat Mentawai membagi hutan mereka kedalam beberapa ketegori yaitu (1) uma dengan pangurep iba; (2) pumonean yang terbagi menjadi dua yaitu (a) pumonean saina; (b) pumonean leleu; dan (3) leleu. Adapun adanya uma dengan pangurep iba sebagai tempat pusat pengatur harta pusaka baik itu tanah ulayat (sibakkat uma, sibakkat porak, dan sibakat leleu), ladang (sibakkat pumonean) dan lainlain. Uma juga merupakan pusat berkumpul dalam setiap urusan baik itu permasalahan dan menyelesaikan masalah dalam keluarga

\footnotetext{
${ }^{12}$ Walaupun lia merupakan kata benda atau kata singkat dari puliajat namun nyatanya lia menandakan pesta-pesta kecil, seperti memperbaiki sapou. Terkadang masyarakat Mentawai melakukan perburuan setelah lia hanya saja perburuan dilakukan dnegan menangkap kekelawar
}

Ute' Simagere (Tengkorak Bagi Roh) atau antar suku lain. Uma juga menjadi tempat kehidupan manusia dan tempat berlangsungnya upacara. Uma dimana memiliki lahan sagu, keladi, sungai semua itu dimanfaatkan untuk kebutuhan seharihari, dan keperluan upacara. Begitu juga dengan adanya pumonean, pumonean saina' yang digunakan untuk kebutuhan sehari-hari dan keperluan upacara baik itu babi dan ayam. Sedangkan pumonean leleu, digunakan pada waktu tertentu sebagai makanan penambah suplai protein, dikarenakan pada musim iba/laggok terang saja buah-buahan berbuah. Sedangkan leleu akan dijadakan tempat berburu ketika pada upacara tertentu sebagaimana yang telah dijelaskan diatas masyarakat Mentawai akan melakuan perburuan, maka leleu menjadi penting bagi mereka untuk suplai protein tambahan selain babi dan ayam.

$$
\text { Penggunaaan lahan menjadi }
$$
penting dalam mengatur ekosistem di Mentawai, pembuatan uma yang merupakan pusat (central) kehidupan manusia dan pusat pengatur lingkungan di Mentawai. Kapan mesti mereka harus melakukan puliaijat, berapa jumlah hewan yang mesti perlu dikorbankan. Kapan mereka mesti beburu, dan kapan mereka mesti membuat ladang dan memanen hasil ladangnya yang juga mendukung keberadaan kehidupan akan hubungan saling memberi dan menerima dalam prinsip ekosistem. Jika mereka memiliki banyak ladang babi dan ladang buah-buahan maka upacara dapat berjalan lancar. Sehingga hubungan mereka dengan dunia supranatural dapat terjaga. Ladang buah-buahan juga merupakan pendukung bagi vegetasi hutan di Siberut, pohon-pohon yang ditanampun merupakan tanaman jangka panjang. Dengan ukuran dan ketinggian pohon yang bisa dimanfaatakan hewan-hewan di Siberut khususnya empat primata endemik di Mentawai. Begitu juga dengan buah-buahan yang dihasilkan dari ladang buah-buahan orang Siberut menjadi makanan ke empat primata ini pada musim iba/laggok materang. Maka dari itu sebagai makhluk yang hidup yang tinggal di dunia purimanuaijat saling memanfaatkan dan terkadang dapat saling mengancam. Maka itu masyarakat Mentawai menjaga hubungan tersebut dengan upacara dan ditutup dengan berburu. 
Adapun entis Mentawai akan melakukan perburuan, seketika pembuatan racun (raggi), pantangan mulai dilakukan bagi setiap pemburu. Bagi yang melanggar maka semua akan medapatkan masalah ketika pergi berburu. Pantangan ini juga menjadi penting bagi orang Mentawai, apaapa saja yang perlu dihindari pada saat berburu nantinya. Adapun ketika berburu dengan cara melihat dan mendengar empat primata ini bersuara, ciri-ciri fisik, dan jejak untuk menandakan hewan buruan. Namun untuk berburu primata ini hanya dilakukan pada pagi, siang dan sore, dikarenakan pada waktu itu mereka bersuara. Sedangkan di malam hari mereka akan tidur. Namun terdapat pantangan tidak boleh mandi yang dijadikan pantangan bagi orang Mentawai agar kondisi cuaca bagus pada saat berburu. Namun nyatanya kondisi cuaca yang tidak menentu menyebabkan terkadang mereka pulang tidak membawa hasil buruan. Begitupun pantangan lainnya, tidak sembarang monyet yang boleh di buru seperti bilou dan joja berwarna putih tidak boleh diburu, sehingga monyet ini suatu waktu menjadi aman dalam incaran para si pemburu.

Lalu bagaimana kehidupan empat primata ini baik itu joja, bokkoi, simakobu dan bilou. Sebagaimana yang sudah dijelaskan empat primata ini akan turun pada musimnya yaitu pada waktu musim iba/laggok materang. Musim iba ini dicirikan dengan banyaknya makanan seperti musim buah-buahan yang menjadi makanan ke empat primata ini. Maka dari itu empat primata ini akan turun ke ladang (pumonean mone) untuk memakan buah-buahan masyarakat. Sedangkan terkhusus untuk bokkoi yang dapat berjalan di tanah. Sehingga bokkoi dapat turun ke pumonean saina' untuk makan makanan babi milik peliharaan etnis Mentawai. Terlihat dari interaksi primata ini terhadap makhluk lainnya, dan itu memberikan keuntungan bagi kehidupan ke empat priamata ini. Namun disisi lain memberikan ancaman bagi kehidupan makhluk lainnya termasuk ancaman ternak orang Mentawai dan ladang orang Mentawai.

Maka dari itu untuk mengatur hubungan tersebut puliaijat dilakukan dalam menjaga keseimbangan antara dunia purimanuaijat dan sabulungan. Dengan intesitas puliaijat dengan berburu tidak selalu dilakukan setiap waktu, dikarenakan aktifitas orang Mentawai untuk menghadapi puliaijat haruslah memiliki banyak persiapan. Dikarenakan sebelum puliaijat sudah banyak eneregi yang perlu dikeluarkan oleh orang Mentawai baik manyagu, mei ka pumonean saina, mei ka pumonean mone. Maka dari itu wujud material dari proses upacara dan berburu di akhiri dengan pembuatan ute' simagere (cultural core), maka hal tersebut menjelaskan pentingnya bagi orang Mentawai dalam mengatur dan menjaga hubungan antara dunia purimanuaijat dan sabulungan. Sehingga ute' simagere dalam upacara dan berburu merupakan mekanisme orang Mentawai dalam menjaga hubungan alam, sosial dan budaya di Mentawai.

\section{KESIMPULAN}

emulanya beberapa sumber
mengatakan orang Mentawai yang
melakukan perburuan yang dapat mengancam kepunahan akan primata itu sendiri. Bahkan pemerintah maupun TNS membatasi para pemburu di Pulau Siberut agar tidak melakukan perburuan lagi. Nyatanya misi konservasi mala membatasi, bahkan pemberian zona-zona itu sendiri melahirkan para HPH dan IPK di Pulau Siberut. Ketika masyarakat Siberut, dianggap terasing pada masa itu, sehinggga perlu pembangunan di Pulau Siberut. Pembangunan yang seperti apa yang harus dilakukan, beberapa perubahan yang mala mengancam keberadaan ekosistem keanekaragaman hayati di sana. Tidak hanya itu orang Mentawai dipromosikan seakan-akan menutupi bahwa orang Mentawai masih menjaga alamnya akibat tergerogoti kemajuan dan perubahan zaman. Zaman neolitikum sudah tergantikan dengan zaman kecangihan. Maka dari itu peneliti mencoba untuk menjelaskan ekosistem yang seperti apa dalam pengetahuan masyarakat Mentawai di Buttui dan Tepu' menjaga keanekaragaman hayatinya terkhususnya keempat primata di Mentawai. Untuk menjelaskan itu peneliti melakuan penelitian pada beberapa suku. Suku ini masih hidup dalam subsisten dan tidak membaur dengan kehidupan modern. Walaupun sesekali mereka sudah mejadi bagian program modern dari pemerintah.

$$
\text { Peneliti menyimpulkan pada }
$$
masyarakat Mentawai mengenal dunia 
mereka terbagi menjadi dua yaitu purimanuaijat yang terdiri dari porak, manua, baga, oinan, dan leleu; dan sabulungan yang terdiri dari Saikamanua, Si Bara Ka Baga, Saikoinan dan Saikaleleu. Adapun dunia nyata ini atau purimanuaijat nyatanya baik itu benda hidup dan benda mati memiliki jiwa (simagere) dan roh (ketcat). Sehingga orang Mentawai harus menjaga hubungan tersebut. Namun tidak hanya itu, dunia purimanuaijat yang hidup berdampingan dengan dunia sabulungan, dikarenakan kehidupan manusia yang selalu memanfaatkan alamnya, dapat memicu hubungan tersebut, sehingga orang Mentawai melakukan upacara punen dan puliaijat. Maka dari itu kepercayaan Arat Sabulungan dengan melakukan upacara dan berburu merupakan mekanisme orang Mentawai dalam menyeimbangkan lingkungan alam, sosial dan budaya. Dikarenakan keseimbangan tersebut tidak hanya menyangkut dunia purimanuaijat, tetapi dunia sabulungan. Terlihat dalam upacara dan berburu, penting bagi masyarakat Mentawai menjaga hubungan sosial sesama makhluk yang berjiwa dan memiliki roh dalam dunia purimanuaijat. Seperti tolong menolong dalam upacara, pembagian otchai kepada sesama suku mereka, kerabat pernikahan, dan suku lain. Namun di sisi lain hubungan sosial terhadap makhluk yang mati juga menjadi penting, seperti hubungan sesama roh-roh nenek moyang keluarga (saukkui), roh-roh penguasa alam (saikamanua, saikabaga, saikaoinan, dan saikaleleu) dan roh dari makhluk lainnya. Terlihat dengan babi dan makanan lainnya mereka akan sembahkan kepada penghuni dunia sabulungan. Begitu juga dengan hewan lainnya yang sudah mati seperti primata, wujud keseimbangan tersebut perlulah dijaga dengan pembuatan bagunan, ute' saina, bakkat katasaila dan diakhiri dengan pembuatan ute' simagere. Secara etno-ekologi orang Mentawai memiliki kategorisasi tentang lingkungan yaitu: (1) uma; (2) pumonean yang terdiri dari pumonenan saina dan pumonean leleu/siburuk; dan (3) leleu. Leleu ini lah menjadi tempat perburuan dan tempat kehidupan bagi 4 jenis primata endemik di Mentawai yaitu bilou, joja, simakobu dan bokkoi. Adapun dengan adanya pumonenan saina dan pumonean leleu, menjadi keuntungan bagi keempat primata ini pada waktu musim iba/laggok materang keempat jenis primata ini akan turun ke ladang buah-buahan, begitu juga dengan bokkoi yang dapat turun ke tanah untuk mengambil surappik di pumunean saina'. Sehingga hal tersebut mendukung keberadaan kehidupan akan hubungan saling memberi dan menerima dalam prinsip ekosistem. Disatu sisi memberikan manfaat kehidupan bagi ke empat primata ini, namun disisi lain memberikan ancaman bagi kehidupan lainnya seperti ternak orang Mentawai dan ladang orang Mentawai. Dilain hal aktifitas masyarakat Mentawai yang memanfaatkan alamnya yang berlebihan, sebagaimana yang dijelaskan pada paragraf pertama, maka upacara menjadi penting dalam menjaga hubungan alam, sosial dan budaya.

Berkaitan dengan aktifitas perburuan primata jika pada upacara merupakan wujud keseimbangan pada hubungan sosial, alam, dan budaya terlihat dengan pembagian makanan sesama suku mereka saja, dan persembahan pada roh nenek moyang dan saikamanua. Namun karena keseimbangan juga menyangkut setiap unsur dalam dunia purimanuiajat dan sabulungan. Maka persembahan tidak hanya cukup terhadap saikamanua, namun berburu dilakukan untuk persembahan hewan buruan dan menghormati roh-roh nenek moyang mereka dan Saikaleleu dengan pembuatan ute' simagere. terlihat pembuatan ute' simagere atau tengkorak primata tersebut diarahkan ke luar uma dan gunung yang memperlihatkan bahwa primata tersebut hewan dari nenek moyang mereka dan saikaleleu. Selain itu mereka juga mementingkan hubungan sesama antar suku, hasil hewan buruan juga akan dibagikan antar suku. Tidak hanya itu hubungan sosial dan budaya terhadap hewan yang disembahkan baik itu hewan peliharaan atau hewan buruan juga terlihat dalam upacara dengan menggantungkan tengkorak primata tersebut. dengan demikian mereka sadar bahwa jiwa yang sudah mati, melainkan tetap hidup dengan wujud pembuatan ute simagere (cultural core). Maka dari itu upacara dan berburu meurapakan mekanisme masyarakat Mentawai menyeimbangkan dunia purimanauaijat dan sabulungan.

Untuk dari itu perburuan bukan semerta mengurangi populasi kempat 
primata ini. Hanya saja upacara merupakan mekanisme agar orang Mentawai dapat mengontrol kehidupan hutan mereka. Begitupun ketika upacara, hanya beberapa upacara saja yang melakukan perburuan dan pada kondisi tertentu. Kemudian upacara tersebut juga membutuhkan waktu yang lama, sehingga ekosistem dapat memperbaiki alamnya seperti semula. Begitupun beberapa pantangan yang menyelamatkan beberapa primata seperti halnya joja simabulau, simabulau dan bilou tidak boleh diburu ataupun hanya bokkoi dan simakobu laki-laki yang disembahkan kepada roh ketika punen eneget. Maka dari itu terwujudlah keseimbangan bagi orang
Mentawai mengenai hubungan antara dunia purimanuaijat dan dunia sabulungan. Keseimbangan itu terwujud ketika mereka dapat memanfaatakan hutan dan segala isinya dengan kapasistas tertentu dan waktu tertentu. Hubungan sosial antara sesama mereka juga terbentuk ketika upacara dan berburu, dalam upacara terlihat pertukaran sosial, pembagian babi, ayam dan makanan lainnya menjadi hal penting di Mentawai (otchai) dan hal yang terpenting juga hubungan sosial dan budaya sesama makhluk mati ataupun hidup yang sudah meninggal agar hubugan mereka tetap dalam keadaan seimbang.

\section{Daftar Pustaka}

Arifin dkk. 2005. Antropologi Ekologi. Laboratorium Antropologi FISIP.

Batchelor, B.C. 1979. Discontinuously rising late Cainozoic sea-levels with special reference to Sundaland, Southeast Asia. Geologie en Mijnbouw 58:1-10.

Coronese, Stefano. 1986. Kebudayaan Suku Mentawai. Jakarta: Grafidian Jaya.

Darmanto dan Setyowati, 2012. Berebut Hutan di Pulau Siberut.

Delfi, Maskota, 2012. Sipuisilam Dalam Selimut Arat Sabulungan Penganut Islam Mentawai di Siberut. Jurnal Al- Ulum Vol.12, Nomor 1.

Fuentes, A. 2002. Monkeys, humans and politics in the Mentawai Islands: no simple solutions in a complex world. Artikel dalam buku Fuentes, A dan Linda D. Wolfe. 2002. Primates Face to Face Conservation implications of human-nonhuman primate interconnections. Cimbridge University.

Fuentes dan Olson. 1995. Preliminary Observations and Status of the Pagai Macaque. Asian Primates. 4 No 4: 1-4.

Kalangie, S. Nico, 1994. Kebudayaan dan Kesehatan Pengembangan Pelayanan Kesehatan Primer Melalui Pendekatan Sosiobudaya. Universitas Indonesia.

Lahajir. 2001. Etnoekologi Perladangan Orang Dayak Tanjung Linggang : Etnografi Lingkungan Hidup di Dataran Tinggi Tunjung.

Miller, G. S. 1903. Seventy New Malayan Mammals Smithsonionan Miscellaneous Collections. hal. 1-73.

Mitchel dan Tilson. 1986. Restoring the Balance: Traditional Hunting and Primate Conservation in the Mentawai Islands, Indonesia.

Mulhadi. 2008. Kepercayaan Tradisional Arat Sabulungan dan Penghapusannya di Mentawai. Jurnal Equality Vol 13 No 1.

Poerwanto, Hari. 2006. Kebudayaan dan Lingkungan dalam Perspektif Antropologi. Pustaka Pelajar. Yogyakarta.

Quinten dkk. 2014. Knowledge, attitudes and practices of local people on Siberut Island (West-Sumatra, Indonesia) towards primate hunting and conservation. Research Gate.

Rappaport, Roy. A. 1968. Pigs for the Ancestor Ritual in the Ecology of a New Guinea People. New Haven: Yale University.

Rudito, Bambang. 2013. Bebetei Uma Kebangkitan Orang Mentawai : Sebuah Etnografi. Gading dan Indonesia Center for Suistainable Development (ICSD). Yogyakarta.

Schefold, Reimar. 1991. Mainan Bagi Roh : Kebudayaan Mentawai. Balai Pustaka. Jakarta. 1988. The Mentawai Equilibrium and the Modern World, in Michael R. Dove, The Real and Imagined Role of Culture in Development. University of Hawaii Press. 
Spina, Bruno. 1981. Mitos dan Lagenda Suku Mentawai. Balai Pustaka. Jakarta.

Suparlan, Parsudi. 2004. Hubungan Antar Suku Bangsa. Jakarta: YPKIK.

Sargis dkk, 2014. Island history affects faunal composition: The treeshrews (Mammalia: Scandentia: Tupaiidae) from the Mentawai and Batu Islands, Indonesia. Research Gate.

Tenaza dan Tilson. 1985. Human Predation and Kloss Gibbon (Hylobatess klossi) Sleeping Trees in Siberut Island, Indonesia. American of Journal Primatology.

Tenaza. R. R. 1990. Conservation of Mentawai Islands Primates and Culture. Biology Departmen, University of Pacific.

Tresno, 2017. Ute' Simagere : Relasi Masyarakat dengan Primata Endemik di Mentawai. Skripsi Jurusan Antropologi, FISIP Universitas Andalas.

Tulius, J. 2012. Stranded People Mythical Narrtives about the First Inhabitants of Mentawai Islands. Wacana Vol 14 No 2.

Waltert dkk, 2008. Abundance and community structure of Mentawai primates in the Peleonan Forest, North Siberut, Indonesia. Research Gate

Wilting dkk, 2012. Mentawai's endemic, relictual fauna: is it evidence for Pleistocene extinctions on Sumatra?. Journal Biogeography. 